\title{
Association between antiretrovirals and thyroid diseases: a cross-sectional study
}

\author{
Guilherme Almeida Rosa da Silva', Mayra Christina Teixeira Andrade', Daniel \\ de Alvarenga Salém Sugui', Rafael Fernandes Nunes', Jorge Francisco da \\ Cunha Pinto', Walter de Araujo Eyer Silva', Fernando Raphael de Almeida \\ Ferry' ${ }^{1}$ Marcelo Costa Velho Mendes de Azevedo', Rogerio Neves Motta'
}

1 Universidade Federal do Estado do Rio de Janeiro (Unirio) Rio de Janeiro, RJ, Brazil
Correspondence to: Guilherme Almeida Rosa da Silva Hospital Universitário Gaffrée e Guinle Rua Mariz e Barros, $775,3^{\circ}$ andar 20270-901 - Rio de Janeiro, RJ Brazil drguialmeida@gmail.com

Received on Aug/28/2014 Accepted on Dec/12/2014

DOI. $10.1590 / 2359-3997000000023$

\begin{abstract}
Objective: This study aims to estimate the prevalence of thyroid diseases and anti-TPO status. We searched for an association among presence of immune reconstitution and use of stavudine, didanosine and protease inhibitors with thyroid diseases. Materials and methods: A cross-sectional study was performed to analyze the records of 117 HIV-infected patients who had their $\mathrm{CD}^{+}$cell count, viral load, anti-TPO, TSH and free $\mathrm{T}_{4}$ levels collected on the same day. Immune reconstitution was considered in those whose T CD4+ count was below $200 \mathrm{cells} / \mathrm{mm}^{3}$, but these values increased above 200 cells $/ \mathrm{mm}^{3}$ after the use of antiretrovirals. The odds ratio obtained by a $2 \times 2$ contingency table and a chi-square test were used to measure the association between categorical variables. Results: The prevalence of thyroid disease was $34.18 \%$; of these, $4.34 \%$ were positive for anti-TPO. There was an association of risk between stavudine use and subclinical hypothyroidism (OR $=4.19,95 \% \mathrm{Cl}: 1.29$ to $\left.13.59, \mathrm{X}^{2}=6.37, \mathrm{p}=0.01\right)$. Immune reconstitution achieved protection associated with thyroid disease that was near statistical significance $\mathrm{OR}=0.45,95 \% \mathrm{Cl}: 0.19$ to $1.04, \mathrm{X}^{2}=3.55, \mathrm{p}=0.059$. Conclusion: The prevalence of thyroid disease in the sample studied was higher than what had been found in the literature, with a low positive anti-TPO frequency. The historical use of stavudine has an association of risk for the presence of subclinical hypothyroidism, and immune reconstitution has trends towards protection for the presence of thyroid diseases. Arch Endocrinol Metab. 2015;59(2):116-22
\end{abstract}

Keywords

AIDS; stavudine; immune reconstitution; thyroid diseases; hypothyroidism

\section{INTRODUCTION}

A IDS is an emerging disease and is one of the largest health problems today because of its pandemic status and severity characteristics. This disease is mainly characterized by a progressive loss of $\mathrm{CD}^{+}{ }^{+} \mathrm{T}$ lymphocytes $\left(\mathrm{CD}^{+}\right)$, which cause immunosuppression and involvement by opportunistic diseases. The natural history of AIDS has been altered considerably by high activity antiretroviral therapy (HAART), which prevents the evolution of the loss of $\mathrm{CD}^{+}$to its final stage. Along with prevention campaigns, HAART contributes to the decline of the transmission and stabilization of the epidemic in many countries ( 1 ).

Nevertheless, several complications have been reported with the use of HAART, among them are hypertriglyceridemia, lipodystrophy, type 2 diabetes mellitus, gonadal dysfunction, and osteoporosis (2). The mechanism by which HAART causes these changes has not been fully elucidated (3-6). Another complication is immune reconstitution inflammatory syndrome (IRIS). This condition occurs in some patients receiving HAART who develop clinical deterioration by the reestablishment of immunity despite high $\mathrm{CD}^{+}$counts and a low plasma viral load. Immune reconstitution (IR) can be defined as an increased $\mathrm{CD} 4{ }^{+}$count above 200 cells $/ \mathrm{mm}^{3}$ in subjects who previously had CD4+ counts lower than 100-200 cells $/ \mathrm{mm}^{3}(7)$.

The development of autoimmune diseases in HIV patients is increasing $(8,9)$. HAART promotes increased patient survival and IR, which could be factors that contribute to autoimmunity. A suggested mechanism of molecular mimesis involves an opportunistic infectious agent that generates an autoimmunity trigger in IRIS or immunodeficient patients (10-12). In immunodeficient patients, as soon as the $\mathrm{CD}^{+}$cells are depleted, autoimmune diseases can be mediated by $\mathrm{CD}^{+} \mathrm{T}$ lymphocytes (13). 
It is possible to relate the stages of HIV infection with the development of autoimmune diseases, which may arise during an acute viral infection (phase I). Autoimmune diseases also occur at the stage of clinical latency, and even without the overt manifestation of AIDS, there is a progressive decline of $\mathrm{CD}^{+}$cells (phase II). When the $\mathrm{CD}^{+}$count becomes profoundly low, autoimmune diseases related to $\mathrm{CD}^{+}$cells are more difficult to develop (phase III). After the initiation of HAART, IR occurs with increased $\mathrm{CD}^{+}$cells in addition to altered immune regulation, which may lead to autoimmune disease (stage IV) (13).

HIV-infected patients have a high overall frequency of autoantibodies, which may be generated as a direct effect of the virus in the endothelium, synovial fluid and hematopoietic cells, leading to the enchantment of the cytotoxic activity of immune cells and autoantigen expression. Increased autoantibody expression, in most cases, is associated with lower $\mathrm{CD}^{+}$cell counts and increased mortality without a relationship with the clinical expression of autoimmune diseases $(13,14)$. Graves' disease, rheumatoid arthritis and, rarely, Hashimoto's thyroiditis were reported as complications of IR (15-17).

Specifically in autoimmune thyroid disease, the prevalence of primary hypothyroidism in AIDS is higher compared with the general population; however, it is not necessarily associated with autoimmunity. The most common cause of primary hypothyroidism in the population is Hashimoto's thyroiditis, which has a prevalence of $0.3 \%(18,19)$. Among HIV-infected individuals, the prevalence of primary hypothyroidism is approximately $2.6 \%(20-22)$.

The prevalence of subclinical hypothyroidism in patients infected with HIV who were not treated varies between $8 \%$ and $10 \%$, with a higher propensity in men. Among HAART users, the prevalence reaches up to $12.6 \%$. Naive patients have a higher prevalence of subclinical hypothyroidism shortly after beginning HAART compared with those who have already been on HAART for at least 1 year, suggesting that thyroid dysfunction associated with medication is acute (23).

A possible manifestation of hypothyroidism in AIDS is dysfunction in the basal secretion of thyroid stimulating hormone (TSH) or central hypothyroidism. The evaluation of TSH in patients with HIV demonstrates a significant reduction of the nocturnal peak at midnight, which is considered to be a sensitive index for evaluating central hypothyroidism (24). Another manifestation consistent with central dysfunction is the pres- ence of isolated low levels of TSH with normal free $\mathrm{T}_{4}\left(\mathrm{FT}_{4}\right)$. This condition was found in 1.3 to $6.8 \%$ of HIV-infected individuals, especially those in advanced disease stages $(20,25-28)$. However, administration of exogenous TSH releasing hormone (TRH) did not alter the response of TSH among individuals with low $\mathrm{FT}_{4}$, making hypothalamic or pituitary insufficiency the least likely scenario (29). Therefore, the clinical significance of a low $\mathrm{FT}_{4}$ levels is not clear because these patients did not experience a higher frequency of hypothyroidism symptoms compared with control subjects. Thyroid function tests may be requested annually, but levothyroxine therapy is not recommended (30).

Euthyroid sick syndrome is characterized by normal or low $\mathrm{FT}_{4}$ levels, low $\mathrm{T}_{3}$ levels, elevated reverse $\mathrm{T}_{3}$ $\left(\mathrm{rT}_{3}\right)$ levels and low or normal TSH levels (31). This is a physiological adaptive phenomenon of the body to conserve energy during periods of extreme stress and during an infection. HIV-infected patients characteristically have increased resting energy expenditure combined with a loss of appetite and subsequent weight loss. The mechanism involved is the reduction in peripheral conversion of $\mathrm{T}_{4}$ to $\mathrm{T}_{3}$, with accumulation of the inactive metabolite $\mathrm{rT}_{3}$. The degree of $\mathrm{rT}_{3}$ elevation and $\mathrm{T}_{3}$ and $\mathrm{T}_{4}$ suppression depends on the severity of the disease or stress. The euthyroid sick syndrome recovery phase can be observed with a transient increase in TSH and normal $\mathrm{FT}_{4}$ and $\mathrm{T}_{3}$ levels. Before the HAART era, this disturbance was a common feature of terminal phase AIDS patients (32).

Thyroid dysfunction among HIV-infected individuals after HAART had an increased prevalence and is linked in most cases to asymptomatic patients, particularly those with subclinical hypothyroidism. Although the mechanism is not clear, stavudine has been suggested as a direct intervening agent in the production and/ or metabolism of thyroid hormones, suggesting the need for monitoring thyroid function in HIV patients who have been treated with this medicine $(25,28,29)$. Drug interactions between protease inhibitors and levothyroxine have also been reported through a shared glucuronidation metabolic pathway. The frequency and clinical impact of these interactions are not known (33).

\section{MATERIALS AND METHODS}

Cross-sectional studies analyzed the medical records of HIV-infected patients on regular outpatients at followup in the Immunology Service of the Gaffrée Guinle 
University Hospital (HUGG), Federal University of the State of Rio de Janeiro (UNIRIO) and were approved by the institution's Ethics in Research Committee.

A total of 421 medical records were reviewed from all of the patients who attended the hospital from March 2013 through August 2013. Of these, 117 records met the inclusion criteria, which included $\mathrm{CD} 4^{+}$ cell counts; HIV viral load; and anti-TPO, TSH and $\mathrm{FT}_{4}$ levels from the same sample. All of the records had information about the age, gender, date of HIV infection diagnosis and HAART history. The exam results were dated from 2012 or 2013 . Patients were demonstrably infected with HIV, aged between 18 and 65 years and were submitted or not to HAART. Because TSH and $\mathrm{FT}_{4}$ levels are not routine tests for HIV patients, 304 records were excluded because of a lack of thyroid function data. A relative sample loss occurred in 17 patients who did not have anti-TPO records. The final sample consisted of 117 patients with complete data and 100 patients with incomplete data because of a lack of anti-TPO results. The database was stored in files from SPSS 17 and in files from Excel 2007.

Patients whose $\mathrm{CD} 4^{+}$counts were below 200 cells $/ \mathrm{mm}^{3}$ but the values of which increased above 200 cells $/ \mathrm{mm}^{3}$ after HAART were included in the IR group. The reference range for TSH was established as normal between 0.5 to $4.5 \mu \mathrm{UI} / \mathrm{L}$, increased $>4.5 \mu \mathrm{UI} / \mathrm{L}$, and decreased $<0.5 \mu \mathrm{UI} / \mathrm{L}$. The reference range for $\mathrm{FT}_{4}$ was established as normal between 0.8 to $1.9 \mathrm{ng} / \mathrm{dL}$, increased > $1.9 \mathrm{ng} / \mathrm{dL}$, and decreased $<0.9 \mathrm{ng} / \mathrm{dL}$. Anti-TPO levels were classified as normal if they were below $35 \mu \mathrm{UI} / \mathrm{mL}$.

Descriptive analyses (means and frequencies) were analyzed using SPSS 17 software. Association measurements among categorical variables, such as the use of stavudine, didanosine and protease inhibitors, and the presence of IR and thyroid diseases were analyzed in a $2 \times 2$ contingency table by measuring the odds ratio $(\mathrm{OR})$. We performed the uncorrected chi-square test $\left(\mathrm{X}^{2}\right)$ using the significance value $(\alpha)$ of 0.05 and degrees of freedom $=1$, which corresponded to a critical value of 3.84. The Epi Info 7 program was used for this statistical analysis.

\section{RESULTS}

After a descriptive and frequency evaluation, the results regarding gender, age, time since diagnosis and antiretroviral status are demonstrated in table 1 . The mean
$\mathrm{CD} 44^{+}$cell count did not differ between the groups, which were ranked according to thyroid dysfunction and measured by TSH levels according to the data contained in table 2 .

Table 1. Descriptive analysis of the sample

\begin{tabular}{lcc}
\hline & N & Mean \pm SD \\
\hline Gender (M/F) & $(68 / 49)$ & - \\
Age (years) & 117 & $43,69 \pm 1,06$ \\
$\begin{array}{l}\text { Time since diagnosis } \\
\text { (months) }\end{array}$ & 117 & $112 \pm 9,1$ \\
HAART (Yes/No) & $(95 / 22)$ & - \\
\hline
\end{tabular}

SD: standard deviation.

Table 2. Mean $\mathrm{CD}^{+}$per groups of thyroid dysfunction measured by TSH $(\mathrm{N}=117 / 117)$

\begin{tabular}{lcc}
\hline $\mathbf{N}$ & TSH & $\begin{array}{c}\mathbf{C D 4}^{+} \\
\text {Mean } \pm \text { SD }\end{array}$ \\
\hline 92 & Increased & $487 \pm 253$ \\
23 & Increased & $543 \pm 346$ \\
2 & Decreased & $488 \pm 171$ \\
117 & - & $498 \pm 272$ \\
\hline
\end{tabular}

$\mathrm{CD} 4^{+}$count measured in cel/mm 3 . SD: standard deviation.

Among 100 patients, 4\% had increased anti-TPO ( $1 \%$ were diagnosed as subclinical hypothyroidism, $1 \%$ as secondary hyperthyroidism, and $2 \%$ had normal TSH and $\mathrm{FT}_{4}$ ).

Using the 117 patients selected for an unrelated anti-TPO analysis, thyroid disease diagnoses, as measured by thyroid function tests and frequency analyses, are contained in table 3 .

Table 3. Analysis of thyroid diseases in the sample $(N=117 / 117)$

\begin{tabular}{lcccc}
\hline $\mathbf{N}$ & TSH & $\mathbf{F T}_{\mathbf{4}}$ & Diagnosis & Percentage \\
\hline 77 & Normal & Normal & Normal & $65,8 \%$ \\
14 & Normal & Decreased & HSouT $^{*}$ & $11,96 \%$ \\
1 & Normal & Increased & HSec $^{* *}$ & $0,85 \%$ \\
15 & Increased & Normal & HP SC $^{* \star *}$ & $12,82 \%$ \\
8 & Increased & Decreased & HP**** $^{* *}$ & $6,83 \%$ \\
1 & Decreased & Decreased & HSouT $^{*}$ & $0,85 \%$ \\
1 & Decreased & Normal & HyperSC $^{* * * *}$ & $0,85 \%$ \\
\hline
\end{tabular}

HSouT*: pituitary/central hypothyroidism or euthyroid sick syndrome; HSec*: secondary hyperthyroidism HP SC ${ }^{\star \star *}$ : subclinical hypothyroidism; $\mathrm{HP}^{\star \star \star *}$ : primary hipothyroidism; Hyper $\mathrm{SC}^{\star \star \star \star \star}$ : subclinical hyperthyroidism.

By analyzing the contingency table and applying the chi-square test, we can identify a not statistically significant association with previous or current stavudine use 
and thyroid disease $(\mathrm{OR}=2.23,95 \% \mathrm{CI}: 0,84$ to 5.93 , $\left.\mathrm{X}^{2}=2.68, \mathrm{p}=0.1\right)$. An analysis within the subclinical hypothyroidism group and according to current stavudine use demonstrated a statistically significant risk association $\left(\mathrm{OR}=4.19,95 \% \mathrm{CI}: 1.29\right.$ to $13.59, \mathrm{X}^{2}=$ $6.37, \mathrm{p}=0.01)$. The same analysis demonstrated no statistically significant association for the primary hypothyroidism $\left(\mathrm{OR}=0.67,95 \% \mathrm{CI}: 0.07\right.$ to $5.82, \mathrm{X}^{2}=$ $0.12, \mathrm{p}=0.72)$ and pituitary/central hypothyroidism or euthyroid sick syndrome group $(\mathrm{OR}=1.25,95 \% \mathrm{CI}$ : 0.31 to $\left.4.91, \mathrm{X}^{2}=0.1, \mathrm{p}=0.74\right)$.

By analyzing the contingency table and applying the chi-square test, we could not identify a statistically significant association with previous or current didanosine use on the presence of thyroid disease $(\mathrm{OR}=1.64$, 95\%CI: 0,64 to $\left.4.16, \mathrm{X}^{2}=1.09, \mathrm{p}=0.29\right)$. Analysis within the subclinical hypothyroidism group and a previous or current history of didanosine use demonstrate an insignificant association $(\mathrm{OR}=2.33,95 \% \mathrm{CI}$ : 0.71 to $\left.7.65, \mathrm{X}^{2}=2.03, \mathrm{p}=0.15\right)$. The same analysis for the primary hypothyroidism $(\mathrm{OR}=0.56,95 \% \mathrm{CI}: 0.06$ to $\left.4.83 \mathrm{X}^{2}=0.27, \mathrm{p}=0.59\right)$, pituitary/central hypothyroidism or euthyroid sick syndrome groups resulted in an insignificant association $(\mathrm{OR}=1.58,95 \% \mathrm{CI}$ : 0.45 to $5.53 \mathrm{X}^{2}=0.53, \mathrm{p}=0.46$ ).

The calculations relating to prior or current protease inhibitor use in the presence of thyroid disease was not significant $\left(\mathrm{OR}=0.64,95 \% \mathrm{CI}: 0.29\right.$ to $1.40, \mathrm{X}^{2}=$ $1.19 \mathrm{p}=0.27$ ). The analysis within the subclinical hypothyroidism group and a history of previous or current protease inhibitor use had an insignificant association $\left(\mathrm{OR}=0.72,95 \% \mathrm{CI}: 0.23\right.$ to $\left.2.17, \mathrm{X}^{2}=0.33 \mathrm{p}=0.56\right)$. The same analysis for the primary hypothyroidism (OR $=0.35,95 \% \mathrm{CI}$ : 0.06 to $\left.1.82, \mathrm{X}^{2}=1.66, \mathrm{p}=0.19\right)$ and pituitary/central hypothyroidism or euthyroid sick syndrome groups $\left(\mathrm{OR}=0.98,95 \% \mathrm{CI}: 0.33\right.$ to $2.91, \mathrm{X}^{2}=$ $0.0008 \mathrm{p}=0.97$ ) resulted in a not significant association.

Statistical analyses were used to identify a protection association between IR and thyroid disease that was close to statistical significance $(\mathrm{OR}=0.45,95 \% \mathrm{CI}$ : 0.19 to $\left.1.04, \mathrm{X}^{2}=3.55, \mathrm{p}=0.059\right)$. Individually, for each type of thyroid disease, there was an insignificant association for subclinical hypothyroidism $(\mathrm{OR}=0.51$, 95\% CI: 0.15 to $1.74, \mathrm{X}^{2}=1.15, \mathrm{p}=0.28$ ), statistically insignificant association from primary hypothyroidism $\left(\mathrm{OR}=0.92,95 \% \mathrm{CI}: 0.2\right.$ to $\left.4.05 \mathrm{X}^{2}=0.01, \mathrm{p}=0.91\right)$ and from pituitary/central hypothyroidism or euthyroid sick syndrome $(\mathrm{OR}=0.5 \mathrm{l}, 95 \% \mathrm{CI}$ : 0.15 to 1.74 , $\left.\mathrm{X}^{2}=1.15, \mathrm{p}=0.28\right)$. The contingency table for the calculations based on different categorical variables is demonstrated in table 4.

\section{DISCUSSION}

Cross-sectional studies have the limitation of not assessing a cause and effect relationship. The proposed study aims to evaluate only associative measures between the categorical variables of IR, use of stavudine, didanosine, and protease inhibitors in the presence of thyroid disease. These antiretrovirals were chosen based on previous publications and by the HAART profile, which was used in the hospital where the study was performed. The sample of HAART users as a whole had a history of using zidovudine and lamivudine, and these patients were excluded from the analysis.

Among HIV-infected individuals, approximately $1 \%$ to $2 \%$ has symptomatic thyroid disease, and up to $35 \%$ may have only subtle abnormalities in thyroid function tests (23). In this study, $6.83 \%$ of patients had TSH values greater than $4.5 \mu \mathrm{UI} / \mathrm{L}$ and $\mathrm{FT}_{4}$ values less than $0.9 \mathrm{ng} / \mathrm{dL}$, which characterized them with primary hypothyroidism. These values were above the averages that had been published previously for HIV-infected individuals, in whom the prevalence was estimated from $2.6 \%$ up to $0.3 \%$ when compared with the general population (19). Subclinical hypothyroidism is characterized by slightly elevated TSH and normal $\mathrm{FT}_{4}$ levels. In the present study, $12.82 \%$ of patients had these characteristics, which kept this result above the average prevalence among HIV-infected persons of 3.5\% to $12.2 \%(20-22)$. This result was elevated with respect to the overall population, for which the prevalence is $4.3 \%$ (19). We can link this response to the genetic and environmental profiles of the study population, issues related to the HIV genotype, or HAART profile history in the sample. Another possible reason is the lack of a definition in the literature relating the TSH baseline and ultrasensitive detection assay development. Further analysis of these assumptions may elucidate a mechanism for the high prevalence of primary hypothyroidism in this population.

Another important finding was the prevalence of $>$ $34 \mu \mathrm{UI} / \mathrm{L}$ anti-TPO in $4 \%$ of patients who had antiTPO measurements. From all of the patients who had anti-TPO measurements, $1 \%$ had increased TSH with normal $\mathrm{FT}_{4}$ levels (subclinical hypothyroidism). In the other $1 \%$, we identified isolated increased $\mathrm{FT}_{4}$ (secondary hyperthyroidism) levels, and another $2 \%$ had normal 
Table 4. Presence of thyroid diseases in patients with or without antiretrovirals

\begin{tabular}{|c|c|c|c|c|c|c|c|c|c|c|c|c|c|c|c|}
\hline \multirow{3}{*}{ HAART } & \multicolumn{14}{|c|}{ Thyroid diseases } & \multirow{3}{*}{ Total } \\
\hline & \multicolumn{2}{|c|}{ Normal } & \multicolumn{2}{|c|}{ Sicks } & \multicolumn{2}{|c|}{ HSouT* } & \multicolumn{2}{|c|}{$\mathrm{HSec}^{\star \star}$} & \multicolumn{2}{|c|}{ HP SC*** } & \multicolumn{2}{|c|}{$H P^{\star \star \star \star \star}$} & \multicolumn{2}{|c|}{$\begin{array}{c}\text { Hyper } \\
\text { SC }^{\star \star \star \star \star \star}\end{array}$} & \\
\hline & + & - & + & - & + & - & + & - & + & - & + & - & + & - & \\
\hline + stavudine & 10 & 10 & 10 & 10 & 3 & 17 & 0 & 20 & 6 & 14 & 1 & 19 & 0 & 20 & 20 \\
\hline - stavudine & 67 & 30 & 30 & 67 & 12 & 85 & 1 & 96 & 9 & 88 & 7 & 90 & 1 & 96 & 97 \\
\hline $\mathrm{OR}$ & \multicolumn{2}{|c|}{0.44} & \multicolumn{2}{|c|}{2.23} & \multicolumn{2}{|c|}{1.25} & \multicolumn{2}{|c|}{ - } & \multicolumn{2}{|c|}{4.19} & \multicolumn{2}{|c|}{0.67} & \multicolumn{2}{|c|}{ - } & \\
\hline Cl95\% & \multicolumn{2}{|c|}{$0.16-1.18$} & \multicolumn{2}{|c|}{$0.84-5.93$} & \multicolumn{2}{|c|}{$0.31-4.91$} & \multicolumn{2}{|c|}{ - } & \multicolumn{2}{|c|}{$1.29-13.59$} & \multicolumn{2}{|c|}{$0.07-5.82$} & \multicolumn{2}{|c|}{ - } & \\
\hline$p$-value & \multicolumn{2}{|c|}{0.1} & \multicolumn{2}{|c|}{0.1} & \multicolumn{2}{|c|}{0.74} & \multicolumn{2}{|c|}{-} & \multicolumn{2}{|c|}{$0.01^{+}$} & & & & & \\
\hline + didanosine & 13 & 10 & 10 & 13 & 4 & 19 & 0 & 23 & 5 & 18 & 1 & 22 & 0 & 23 & 23 \\
\hline - didanosine & 64 & 30 & 30 & 64 & 11 & 83 & 1 & 93 & 10 & 84 & 7 & 87 & 1 & 93 & 94 \\
\hline OR & & & & & & & & & & & & & & & \\
\hline $\mathrm{Cl95 \%}$ & 0.24 & & & & 0.4 & & & & & & & & & & \\
\hline$p$-value & & & & & & & & & & & & & & & \\
\hline$+\mathrm{Pl}$ & 39 & 16 & 16 & 39 & 7 & 48 & 0 & 55 & 6 & 49 & 2 & 53 & 0 & 55 & 55 \\
\hline$-\mathrm{PI}$ & 38 & 24 & 24 & 38 & 8 & 54 & 1 & 61 & 9 & 53 & 6 & 56 & 1 & 61 & 62 \\
\hline $\mathrm{OR}$ & & & & & & & & & & & & & & & \\
\hline Cl95\% & 0.71 & & & & 0.3 & & & & & & & 82 & & & \\
\hline$p$-value & & & & & & & & & & & & & & & \\
\hline$+\mathbb{R}$ & 35 & 11 & 11 & 35 & 4 & 42 & 0 & 46 & 4 & 42 & 3 & 43 & 0 & 46 & 46 \\
\hline - $\mathbb{R}$ & 42 & 29 & 29 & 42 & 11 & 60 & 1 & 70 & 11 & 60 & 5 & 66 & 1 & 70 & 71 \\
\hline OR & & & & & & & & & & & & & & & \\
\hline Cl95\% & 0.96 & & & & 0.1 & & & & & & & .74 & & & \\
\hline$p$-value & & & & & & & & & & & & & & & \\
\hline Total & 77 & 40 & 40 & 77 & 15 & 102 & 1 & 116 & 15 & 102 & 8 & 109 & 1 & 116 & 117 \\
\hline
\end{tabular}

HSouT $^{\star}$ : pituitary/central hypothyroidism or euthyroid sick syndrome; HSec ${ }^{\star \star}$ : secondary hyperthyroidism; HP SC ${ }^{\star \star \star}$ : subclinical hypothyroidism; HP ${ }^{\star \star \star \star}$ : primary hypothyroidism; Hyper SC ${ }^{\star \star \star \star \star}$ : subclinical hyperthyroidism; IR: immune reconstitution; PI: protease inhibitors; + Statistically significant $(\mathrm{p}<0.05)$, - undefined.

thyroid function. In the general population, hypothyroidism is most commonly caused by autoimmune thyroid destruction, in which $90 \%$ of cases were anti-TPO positive (34). In our study, only one of 23 patients was diagnosed with hypothyroidism or subclinical hypothyroidism and had positive anti-TPO values $(4.34 \%)$. This value is below what is expected for the general population and gives consistency to the scientific evidence that HIV-infected patients with primary hypothyroidism have lower anti-TPO positivity $(20,32)$. The absence of anti-TPO does not mean that the patients do not have thyroid autoimmune disease. Tissue biopsies and imaging tests, such as an ultrasound, are necessary to identify whether patients with anti-TPO also demonstrate an absence of lymphocytic infiltration and heterogeneous aspects of the gland, which are characteristic of Hashimoto's thyroiditis.

The onset of Graves' disease appears to be possible after the IR. There are few case reports of Hashimoto's thyroiditis that developed after initiating HAART
(35). In the present study, there was an association of protection that was very close to reaching statistical significance that was related to thyroid disease in the presence of IR history. This trend suggests that most thyroid dysfunction in AIDS cases are not immunemediated but are related to specific antiretroviral drugs and the presence of disease activity as in the euthyroid sick syndrome.

The use of stavudine has been associated with subclinical hypothyroidism in a few studies. In one prospective study, abnormalities in thyroid function were found in $12.6 \%$. Patients on stavudine had significantly lower FT4 levels with prolonged treatment (25). In other study, the prevalence of subclinical hypothyroidism was $12.2 \%$ and the previous use of PI, especially stavudine, had a statistically significant risk association for hypothyroidism when compared to naïve patients $(\mathrm{p}<0.05)(29)$. As in the previously cited studies, an association of risk was observed among the historical use of stavudine and subclinical hypothyroidism OR = 
4.19, 95\%CI: 1.29 to $\left.13.59, \mathrm{X}^{2}=6.37, \mathrm{p}=0.01\right)$. The underlying mechanisms involved in this association are unclear and deserve further investigation. The association analysis between stavudine use and thyroid diseases (general thyroid diseases, pituitary/central hypothyroidism, euthyroid sick syndrome, secondary hyperthyroidism, primary hypothyroidism or subclinical hyperthyroidism) was not statistically significant.

Isolated low $\mathrm{FT}_{4}$ levels with normal or low TSH levels are frequently observed among HIV-infected individuals with a prevalence of $1.3 \%$ to $6.8 \%(20,26-28)$. Within these results, the value in our study was higher than the average because $11.96 \%$ of patients had normal TSH and low $\mathrm{FT}_{4}$ levels. In some cases, euthyroid sick syndrome or pituitary or hypothalamus failure can lead to central hypothyroidism (secondary or tertiary). In such cases, $\mathrm{FT}_{4}$ concentrations are low, and TSH concentrations can be low or in the normal range.

In patients with low thyroid hormone levels and normal or low TSH (1 patient $=0.85 \%$ ) levels, pituitary/central hypothyroidism or euthyroid sick syndrome needs to be considered. Euthyroid sick syndrome occurs during severe illnesses, including advanced AIDS, where the most common pattern of thyroid function is reduced $\mathrm{T}_{3}$ levels, high $\mathrm{rT}_{3}$ levels, varying $\mathrm{FT}_{4}$ levels, and normal or decreased TSH levels, depending upon disease severity. However, a smaller increase of $\mathrm{rT}_{3}$ levels was observed among patients with advanced AIDS (33). During disease recovery, TSH levels may increase temporarily, sometimes exceeding the normal range, thus returning $\mathrm{FT}_{4}$ and $\mathrm{T}_{3}$ levels to normal values, mimicking subclinical hypothyroidism. Among the HIV-infected population, the highest frequency of thyroid disease was reported in patients with terminal AIDS before HAART, with up to $16 \%$ of patients affected (30). In this study, $\mathrm{TSH}$ and $\mathrm{FT}_{4}$ levels were obtained in low levels in only one patient $(0.85 \%)$. rT3 measurement in individuals that are not suspected of having thyroid disease is not recommended and was not performed. The sum of patients with normal or low TSH and low $\mathrm{FT}_{4}$ levels totaled 15 (12.82\%), which was higher than expected for HIV (1.3\% to $6.8 \%)(20,26-28)$.

We conclude that the prevalence of thyroid disease in the sample studied was higher than what had been found in the literature, with a low positive anti-TPO frequency. The historical use of stavudine has an association of risk for the presence of subclinical hypothyroidism, and IR has a protection association close to statistical significance for the presence of thyroid diseases.
Financial support: there was no financial support for this work.

Disclosure: no potential conflict of interest relevant to this article was reported.

\section{REFERENCES}

1. Miller V, Hodder S. Beneficial impact of antiretroviral therapy on non-AIDS mortality. AIDS. 2014;28(2):273-4.

2. Brockmeyer N, Kreuter A, Bader A, Seemann U, Reimann G. Prevalence of endocrine dysfunction in HIV-infected men. Horm Res. 2000;54(5-6):294-5.

3. Aukrust P, Liabakk NB, Müller F, Lien E, Espevik T, Frøland SS. Serum levels of tumor necrosis factor (TNF) $\triangle$ and soluble TNF receptors in human immunodeficiency virus type 1 infectioncorrelations to clinical, immunologic, and virologic parameters. J Infect Dis. 1994;169 (2):420-4.

4. Serrano S, Marinoso ML, Soriano JC, Rubies-Prat J, Aubia J, Coll $\mathrm{J}$, et al. Bone remodelling in human immunodeficiency virus-1 infected patients. A histomorphometric study. Bone. 1995;16(2):18591.

5. Pacifici R. Estrogen, cytokines, and pathogenesis of postmenopausal osteoporosis. J Bone Min Res. 1996;11(8):1043-51.

6. Poli V, Balena R, Fattori E, Markatos A, Yamamoto M, Tanaka H, et al. Interleukin- 6 deficient mice are protected from bone loss caused by estrogen depletion. EMBO J. 1994;13(5):1189-96.

7. da Silva GAR, Azevedo MCVM, Motta RN, Pinto JFC, Sá CAM, Ferry FRA. Herpes zoster oftálmico como manifestação de síndrome de reconstituição imune em um paciente com AIDS. Relato de Caso Cad Bras Med. 2012;25:15-8.

8. Reveille JD. The changing spectrum of rheumatic disease in human immunodeficiency virus infection. Semin Arthritis Rheum. 2000;30(3):147-66.

9. Cuellar ML. HIV infection-associated inflammatory musculoskeletal disorders. Rheum Dis Clinics N Am. 1998;24(2):403-21.

10. Deas JE, Liu LG, Thompson JJ. Reactivity of sera from systemic lupus erythematosus and Sjogren's syndrome patients with peptides derived from human immunodeficiency virus p24 capsid antigen. Clin Diagn Lab Immunol. 1998;5(2):181-5.

11. Shoenfeld Y. Common infections, idiotypic dysregulation, autoantibody spread and induction of autoimmune diseases. J Autoimmun. 1996;9(2):235-9.

12. Shoenfeld CY. The viral autoimmunity relationship. Viral Immunol. 1995;8(1):1-9.

13. Zandman-Goddard G, ShoenfeldY. HIV and autoimmunity. Autoimmun Rev. 2002;1(6):329-37.

14. Massabki PS, Accetturi C, Nishie IA, da Silva NP, Sato El, Andrade LE. Clinical implications of autoantibodies in HIV infection. AIDS. 1997;11(15):1845-50.

15. Crum NF, Ganesan A, Johns ST, Wallace MR. Graves' disease: an increasingly recognized immune reconstitution syndrome. AIDS. 2006;20(3):466-9.

16. Hoffman CJ, Brown TT. Thyroid function abnormalities in HIV infected patients. Clin Infect Dis. 2007;45(4):488-94.

17. Bell $C$, Nelson $M$, Kaye $S$. A case of immune reconstitution rheumatoid arthritis. Int J STD AIDS. 2002;13(8):580-1.

18. Golden $\mathrm{SH}$, Robinson KA, Saldanha I, Anton B, Ladenson PW. Prevalence and incidence of endocrine and metabolic disorders in the United States: a comprehensive review. J Clin Endocrinol Metab. 2009;94(6):1853-78.

19. Hollowell JG, Staehling NW, Flanders WD, Hannon WH, Gunter EW, Spencer CA. Serum TSH, T(4), and thyroid antibodies in the 
United States population (1988 to 1994): National Health and Nutrition Examination Survey (NHANES III). J Clin Endocrinol Metab. 2002;87(2):489-99.

20. Beltran S, Lescure FX, El Esper I, Schmit JL, Desailloud R. Subclinical hypothyroidism in HIV infected patients is not an autoimmune disease. Horm Res. 2006;66(1):21-6.

21. Madge S, Smith CJ, Lampe FC, Thomas M, Johnson MA, Youle M, et al. No association between HIV disease and its treatment and thyroid function. HIV Med. 2006;8(1):22-7.

22. Noureldeen A, Qusti SY, Khoja GM. Thyroid function in newly diagnosed HIV-infected patients. Toxicol Ind Health. 2014;30(10): 919-25.

23. Parsa AA, Bhangoo A. HIV and thyroid dysfunction. Rev Endocr Metab Disord. 2013;14(2):127-31.

24. Spinola-Castro AM, Siviero-Miachon AA, da Silva MTN, GuerraJunior G. O papel do hormônio de crescimento no tratamento dos distúrbios endócrino-metabólicos do paciente com a síndrome da imunodeficiência adquirida (Aids). Arq Bras Endocrinol Metab. 2008;52(5):818-32.

25. Madeddu G, Spanu A, Chessa F, Calia GM, Lovigu C, Solinas P, et al. Thyroid function in human immunodeficiency virus patients treated with highly active anti-retroviral therapy (HAART): a longitudinal study. Clin Endocrinol. 2006;64(4):375-83.

26. Sellmeyer DE, Grrunfeld C. Endocrine and metabolic disturbances in human immunodeficiency virus infection and the acquired immune deficiency syndrome. Endocr Rev. 1996;17(5):518-32.
27. Dobs AS, Dempsy MA, Ladenson PW, Polk BF. Endocrine disorders in men infected with the human immunodeficiency virus. Am J Med. 1988;84(3 Pt 2):611-6.

28. Raffi F, Brisseau JM, Planchon B, Rémi JP, Barrier JH, Grolleau JY. Endocrine function in 98 HIV infected patients: a prospective study. AIDS. 1991;5(6):729-33.

29. Calza L, Manfredi R, Chiodo F. Subclinical hypothyroidism in HIVinfected patients receiving highly active antiretroviral therapy. $J$ Acquir Immune Defic Syndr. 2002;31(3):361-3.

30. Merenich J, McDermott T, Asp A, Harrison SM, Kidd GS. Evidence of endocrine involvement early in the course of human immunodeficiency virus infection. J Clin Endocrinol Metab. 1990;70(3):566-71.

31. LoPresti JS, Fried JC, Spencer CA, Nicoloff JT. Unique alterations of thyroid hormone indices in the acquired immunodeficiency syndrome. Ann Intern Med. 1989;110(12):970-5.

32. Hoffman CJ, Brown TT. Thyroid function abnormalities in HIV infected patients. Clin Infect Dis. 2007;45(4):488-94.

33. Touzot M, Le Beller C, Touzot F, Lou M, Piketty C. Dramatic interaction between levothyroxine lopinavir/ritonavir in an HIV-infected patient. AIDS. 2006;20(8):1210-2.

34. Saravanan $\mathrm{P}$, Dayan CM. Assessment of thyroid function disease: thyroid autoantibodies. Endocrin Metab Clin. 2001;30(2):315-37.

35. Rosenfeld CR, Calabrese LH. Progression of autoimmune thyroiditis in an HIV-infected woman on HAART. AIDS Read. 1999;9(6):393-4. 